\title{
The Effect of Bone Marrow Mesenchymal Stem Cells Versus Methotrexate on the Knee Joint in A Rat Model of Rheumatoid Arthritis. A Histological Study
}

Original Article

\author{
Somaya Abdel-Alim Mohammed, Noha Abdel-Hakam Makhlouf, Walaa Baher \\ and Shimaa Mohammed Aboud.
}

Histology \& Cell Biology Department, Faculty of Medicine, Ain Shams University

\begin{abstract}
Background and objectives: Rheumatoid arthritis (RA) is an autoimmune disease characterized by chronic progressive joint inflammation with subsequent cartilage destruction. This study was conducted to evaluate and compare the effect of bone marrow mesenchymal stem cells (BM-MSCs) versus Methotrexate (MTX) on knee joint in a rat model of RA.

Materials and Methods: Thirty-five adult male albino rats were divided into two groups. Group I: control group (15 rats). Group II (20 rats) in which RA was induced, and then the rats were subdivided into four subgroups. Subgroups IIa and IIb were sacrificed two and four weeks after induction of RA respectively. Subgroups IIc and IId were treated by MTX and BM-MSCs respectively after two weeks of induction of RA and were sacrificed after further two weeks. The knee joints were collected, decalcified and processed for histological, histochemical, immunehistochemical and morphometric studies.

Results: Histological examination of the knee joints revealed that RA resulted in thickening of the intimal lining of the synovial membrane, infiltration, congestion and increased collagen content of the subintima. The articular cartilage showed erosions, thinning, cell and ground substance loss and increased expression of inducible nitric oxide synthase (iNOS). Injection of BM-MSCs resulted in improvement of the structure of the synovial membrane and the articular cartilage of the knee joint whereas, injection of MTX was relatively less effective.

Conclusion: Intra- articular injection of BM-MSCs resulted in a significant improvement in the histological structure of the knee joint in comparison to MTX in a rat model of RA.
\end{abstract}

Key Words: Bone marrow-mesenchymal stem cells, Knee joint, Methotrexate, Rheumatoid arthritis, Synovial membrane.

Revised: 06 October 2018, Accepted: 22 October 2018

Corresponding Author: Walaa Baher, Department of Histology \& Cell Biology, Faculty of Medicine, Ain Shams University, Abasyia, Cairo 11358, Egypt, Tel.: +20-1002050563, Fax: +20-222909854, E-mail: Walaa_baher@med.asu.edu.eg.

ISSN: 1110-0559, Vol. 2, No. 1

\section{INTRODUCTION}

Rheumatoid arthritis (RA) is a chronic, poly-articular, inflammatory and destructive autoimmune disease that does not result from a single factor or single environmental exposure. Yet, the pathophysiology of the disease requires combination of genetic and non-genetic factors as hormonal and environmental factors ${ }^{[1]}$.

The disease is characterized by chronic progressive joint inflammation with subsequent cartilage and bone destruction. Rheumatoid arthritis could be either primary that occurs alone or secondary that occurs in association with other autoimmune disease as lupus, interstitial lung disease and vasculitis $^{[2]}$.

Currently, there is no optimal therapy for RA except for systemic immune-suppressants which have serious side effects. One of these is Methotrexate which is a commonly used drug in the treatment of RA. Despite its efficacy, it is not well tolerated by most patients because of its serious adverse effects $^{[3]}$.
The need for other treatment modalities has emerged in an attempt to develop a treating agent that is effective as MTX but devoid of its serious side effects. One of these recently tried methods is the use of mesenchymal stem cells as they were found to differentiate into variety of mesenchymal tissue as bone, cartilage, muscle and adipose tissue ${ }^{[4]}$.

Several studies suggested that BM-MSCs might have ameliorative effect on joint destruction with induction of cartilage regeneration ${ }^{[5-7]}$. On the contrary, other studies proposed that BM-MSCs had little therapeutic role in the treatment of RA induced in rats especially when administrated at the late stage of the disease $\mathrm{e}^{[8,9]}$.

One of the most widely used arthritis models is a single injection of complete Freund's adjuvant (CFA) which is formed of a mixture of paraffin oils, mannide monooleate, and heat-killed mycobacteria ${ }^{[10]}$.

The purpose of this study was to explore and compare the effect of MTX and MSCs on the histological structure of the knee joint in a rat model of RA. 


\section{MATERIALS AND METHODS}

\section{Animal groups}

The experiment included 35 adult Wister male albino rats (weighing 150 - $200 \mathrm{gm}$ ). Animals were purchased from and housed in Medical Research Center (MASRI), Faculty of Medicine, Ain Shams university. The animals were kept in wire mesh cages and were allowed a free access to standard chow diet and tap water. All the experimental procedures were performed in accordance with guidelines of scientific research ethics committee of Faculty of Medicine, Ain Shams University.

Experimental animals were randomly divided into two main groups:

Group I (Control group, $\mathrm{n}=15$ ), further subdivided into four subgroups corresponding to the experimental subgroups. Subgroup Ia ( $\mathrm{n}=3)$, negative control group. Subgroup Ib (RA control, $n=6$ ), received a single subcutaneous injection of 0.3 $\mathrm{ml}$ normal saline (solvent of CFA) in the metatarsal footpad of right hind limb using insulin syringe. Three rats were sacrificed after two weeks and another three rats after four weeks. Subgroup Ic (MTX control, $n=3$ ), received normal saline in the same dose and route as subgroup Ib. After two weeks, another twice weekly subcutaneous injections of 0.3 $\mathrm{ml}$ saline (dilute of MTX) was given for further 2 weeks then sacrificed and Subgroup Id (BM-MSCs control, $n=3$ ), received normal saline in the same dose and route as subgroup Ib. After two weeks, a single intra-articular injection of 0.25 $\mathrm{ml}$ phosphate buffered saline (the vehicle of stem cell) in the left knee joint was given then the rats were sacrificed after further two weeks.

Group II (Experimental group, $\mathrm{n}=20$ ), RA was induced using a single subcutaneous injection of $0.1 \mathrm{ml}$ of CFA (Sigma-Aldrich, USA) suspended in 0.2 normal saline in the metatarsal footpad of right hind limb ${ }^{[11]}$. Animals of this group were further subdivided into four equal subgroups ( 5 animals each):

Subgroup IIa: Rats were sacrificed after two weeks from the injection of CFA to confirm induction of RA (early RA). Subgroup IIb: Rats were sacrificed after four weeks from injection of CFA (late RA). Subgroup IIc (MTX treated group): Rats were left for two weeks after injection of CFA, then received twice weekly subcutaneous injection of $0.3 \mathrm{mg} /$ kg MTX (Sandoz Swiss Company) for another two weeks, then sacrificed ${ }^{[12]}$; and Subgroup IId (BM-MSCs treated group): Rats were left for two weeks after injection of CFA, then received single intra-articular injection of $\mathrm{PKH} 26$ labeled MSCs in the left knee joint in a concentration of $2 \times 10^{6}$, then sacrificed after further two weeks.

\section{Histological studies}

At the end of the experiment, all animals were sacrificed after ether inhalation anesthesia. Left knee joints were dissected, trimmed of skin and muscles and were fixed in a solution of 5.5gm ethylene-diamine-tetra-acetic acid (EDTA) dissolved in $90 \mathrm{ml}$ distilled water and $10 \mathrm{ml}$ formaldehyde. Daily change of the solution was done for six weeks until softening of specimens was obtained. Then specimens were dehydrated, cleared, embedded in paraffin and cut into serial sections of $5 \mu \mathrm{m}$ thickness then stained with different histological stains (H\&E and Masson's trichrome $)^{[13]}$, histochemical stains (Safranin O) for cartilage matrix ${ }^{[13]}$ and immunehistochemical avidine-biotin peroxidase technique for detection of a proinflammatory cytokine; inducible nitric oxide synthase (iNOS $)^{[14]}$. To confirm the specificity of immune staining, the primary antibody was replaced with heat attenuated normal rat serum (negative control). Another two cartilage sections from subgroup IIb were stained with the substrate solution with or without the inhibitor of alkaline phosphatase to exclude the possibility of nonspecific labeling.

\section{Culture of BM-MSCs (15)}

The isolated BM-MSCs were cultured in complete culture medium (Dulbecco's modified Eagle's medium "DMEM", Sigma Aldrich, USA) supplemented with $1 \%$ penicillinstreptomycin in sterile tissue culture dishes and incubated in a standard air/CO2 incubator at $37^{\circ} \mathrm{C}$. Mesechymal stem cells were distinguished from other bone marrow cells by their tendency to adhere to the tissue culture flasks and dishes (Figs. 1a,1b)

On reaching more than $75 \%$ confluence (Fig. 1c) subculture was performed by washing cells with PBS (1 or 2 times), followed by addition of $2.5 \mathrm{ml}$ of Trypsin-EDTA for 5 minutes at $37^{\circ} \mathrm{C}$ inside the incubator. The action of TrypsinEDTA was stopped by complete culture medium and the detached cells suspension was spinned down at 15002000 RPM for 10 minutes. The cells in the precipitated cell pellet were counted and tested for viability using haemocytometer.

\section{Characterizations of the cultured BM- MSCs}

On day five of the primary culture two petri dishes were spared and prepared for characterized of BM-MSCs using immune-histochemical staining for CD $44^{[16]}$ (Fig. 1d).

\section{Fluorescence labeling of stem cells by $\mathrm{PKH} 26$ dye for in vivo tracking of BM-MSCs}

Labeling of stem cells was done after the third passage as described by the supplier (Sigma- Aldrich, Catalog Numbers MINI26, MIDI26 and PKH26GL). For testing viability of PKH26-labeled primary BM-MSCs, they were re-cultured. Fluorescent microscope examination of cartilage specimens of rats treated with the labeled cells (subgroup IId) was done to insure their incorporation into tissues (Fig. 1e).

N.B. Isolation, culturing and labeling of stem cells were done at Biochemistry department, Faculty of Medicine, Cairo University. 


\section{Morphometric measurements:}

The following parameters were measured in randomly chosen five fields/section, in five sections for every rat in each subgroup, at a constant magnification for each parameter.

The cartilage thickness in micrometers $(\mu \mathrm{m})$ in $\mathrm{H} \& \mathrm{E}$ stained sections, the staining density of the cartilage matrix in Safranin O stained sections, the number of iNOS positive chondrocytes $\left(\right.$ cells $\left./ \mu \mathrm{m}^{2}\right)$ in immunohistochemically stained sections and area percentage of collagen fibers in the synovial membrane in Masson's trichrome stained sections.

All measurements were performed using Leica microscope DM 2500 connected to a camera (Leica DFC 295) and Leica Q win V3 image analysis software (Leica microsystems, Germany) at image analysis unit, Histology and Cell Biology Department, Faculty of Medicine, Ain Shams University.

\section{Statistical analysis}

All values of the morphometric results were expressed as mean \pm standard deviation (SD). Statistical analysis was carried out using Statistical Package for Social Sciences (SPSS), software program, version 20 (IBM Corporation, Armonk, New York, USA). Statistical difference among groups was determined using two-way analysis of variance (ANOVA) followed by post hoc least significance difference (LSD) for comparison between more than two groups. P values $<0.05$ were considered statistically significant.

\section{RESULTS:}

\section{Light microscopic results:}

Sections of the control subgroups stained with $H \& E$ showed almost similar histological structure. The articular cartilage surface was smooth, the chondrocytes were arranged into zones; Superficial tangential zone; in which chondrocytes were arranged with their longitudinal axis parallel to the articular surface, middle zone; in which chondrocytes were rounded and scattered, and deep zone; in which chondrocytes were arranged into parallel columns perpendicular to the articular surface. Tidemarks appeared as transverse lines separating the deep cartilage zone from the underlying calcified zone (Fig.2a).

In subgroup IIa (early RA), the articular surface was irregular with scattered erosions. Some lacunae appeared empty while others showed shrunken chondrocytes with pyknotic nuclei. Some areas showed loss of chondrocytes and fissuring of the cartilage matrix. Multiple scattered isogenous cell groups were also observed (Fig $2 b$ ). In subgroup IIb (late RA), marked irregularities of the articular surface with frequent surface erosions and areas of chondrocytes' loss were observed. The middle zone showed discontinuity of the matrix, large empty lacunae and degenerated shrunken chondrocyte with pyknotic nuclei. Many scattered isogenous cell groups were detected. Apparent thinning of the articular cartilage was also noticed with ill- defined tidemark (Fig.2c).

In subgroup IIc (MTX treated), the articular surface was regular and smooth. The cartilage matrix was continuous. Chondrocytes appeared occupying their lacunar spaces and were grouped in clusters or isogenous groups, although they were poorly organized into layers compared to the control group. The tidemark was evident (Fig. 2d).

In subgroup IId (MSCs treated), the articular surface was smooth. Chondrocyte appeared occupying their lacunar spaces. The cartilage matrix was intact, and chondrocytes were almost organized into layers comparable to the control group. (Fig 2e).

As regards the synovial membrane, the control group demonstrated thin intimal lining formed of one to two layers of synovial cells. The subintimal stroma was formed of adipose connective tissue with few scattered thin walled blood vessels (Fig 3a). Few scattered collagen fibers in the subintimal stroma of the synovial membrane was seen in Masson's trichrome stained sections (Figs 4a).

Subgroup IIa (early RA), showed thickening of the intimal lining, and the subintimal stroma showed inflammatory cells, and dilated congested blood vessels (Fig 3b) with an apparent increase in the collagen fiber content in comparison to the control group (Fig $4 \mathrm{~b}$ ). In subgroup IIb (late RA), the intimal lining showed marked thickening with villous formation. Subintimal stroma showed inflammatory cells infiltration and congested blood vessels (Fig 3c) and an apparent increase in the collagen fiber content in the subintimal stroma (Fig4c).

Subgroup IIc (MTX treated), demonstrated relatively thin lining of the intima and the subintimal stroma showed few scattered inflammatory cells, and some congested dilated blood vessels (Fig 3d) and an apparent decrease in the collagen fiber content was noticed in the subintimal stroma as compared to subgroups IIa and IIb (Fig4d).

Subgroup IId (MSCs treated), showed relatively thin intimal lining with minimal inflammatory cells (Fig. 3e). Apparent few scattered collagen fibers in the subintimal stroma was noticed as compared to the other experimental subgroups (Fig. 4e).

Safranin O stain of the control group showed homogenous orange color of the ground substance of the articular cartilage (Fig. 5a).

In subgroups IIa and IIb (early \& late RA), apparent decrease in the intensity of Safranin O stain as compared to the control (Figs. $5 \mathrm{~b}$ and $5 \mathrm{c}$ respectively) was noticed.

In subgroups IIc and IId (MTX \& MSCs treated), apparent increase in the staining intensity of Safranin $\mathrm{O}$ stain of the cartilage ground substance was noticed especially in the upper zone in subgroup IIc (Fig. 5d) and in the upper and lower zones in subgroup IId (Fig 5e) as compared to subgroups IIa and IIb. 
Immunostaining for iNOS showed negative iNOS immunostaining of chondrocytes in the control group (Fig. 6a). In subgroups IIa and IIb, many iNOS-positive chondrocytes were detected (Figs. $6 \mathrm{~b} \& 6 \mathrm{c}$ ), whereas, fewer iNOS-positive chondrocytes were seen in subgroups IIc and IId (Figs. $6 \mathrm{~d} \&$ 6e respectively) as compared to the untreated subgroups (IIa and IIb).

\section{Morphometric and statistical results:}

Cartilage thickness in the treated subgroups whether by MTX (subgroup IIc) or by BM-MSCs (subgroup IId) showed a non-significant change $(\mathrm{P}>0.05)$ in comparison to the control group. On the contrary, untreated subgroups displayed a significant decrease $(\mathrm{P}<0.05)$ in comparison to the control group and treated subgroups (Table. 1).

The color density of Safranin O stain in the ground substance recorded its peak in subgroup IId (BM-MSCs treated) to be almost comparable to that of the control group, on the other hand, subgroup IIc (MTX treated) showed a significant decrease $(\mathrm{P}<0.05)$ as compared to both group I and subgroup IId. Non significant change $(\mathrm{P}>0.05)$ was detected in the color density of Safranin O between subgroup IIa and subgroup IIc (Table. 1).

In subgroups IIa and IIb, the number of iNOS positive chondrocytes was significantly increased $(\mathrm{P}<0.05)$ in comparison to the group I and subgroup IId. Subgroup IIc showed a significant increase $(\mathrm{P}<0.05)$ in comparison to group I and a non-significant change $(\mathrm{P}>0.05)$ in comparison to subgroup IId. A non-significant change $(\mathrm{P}>0.05)$ was estimated between group I and subgroup IId (Table. 1).

Area percentage of collagen fibers in the synovial membrane showed a non-significant change $(\mathrm{P}>0.05)$ between group I and subgroup IId. On the contrary, subgroups IIa, IIb and IIc showed a significant increase $(\mathrm{P}<0.05)$ in comparison to group I and subgroup IId. Subgroup IIc showed a significant decrease $(\mathrm{P}<0.05)$ in comparison to subgroups IIa and IIb (Table 1).

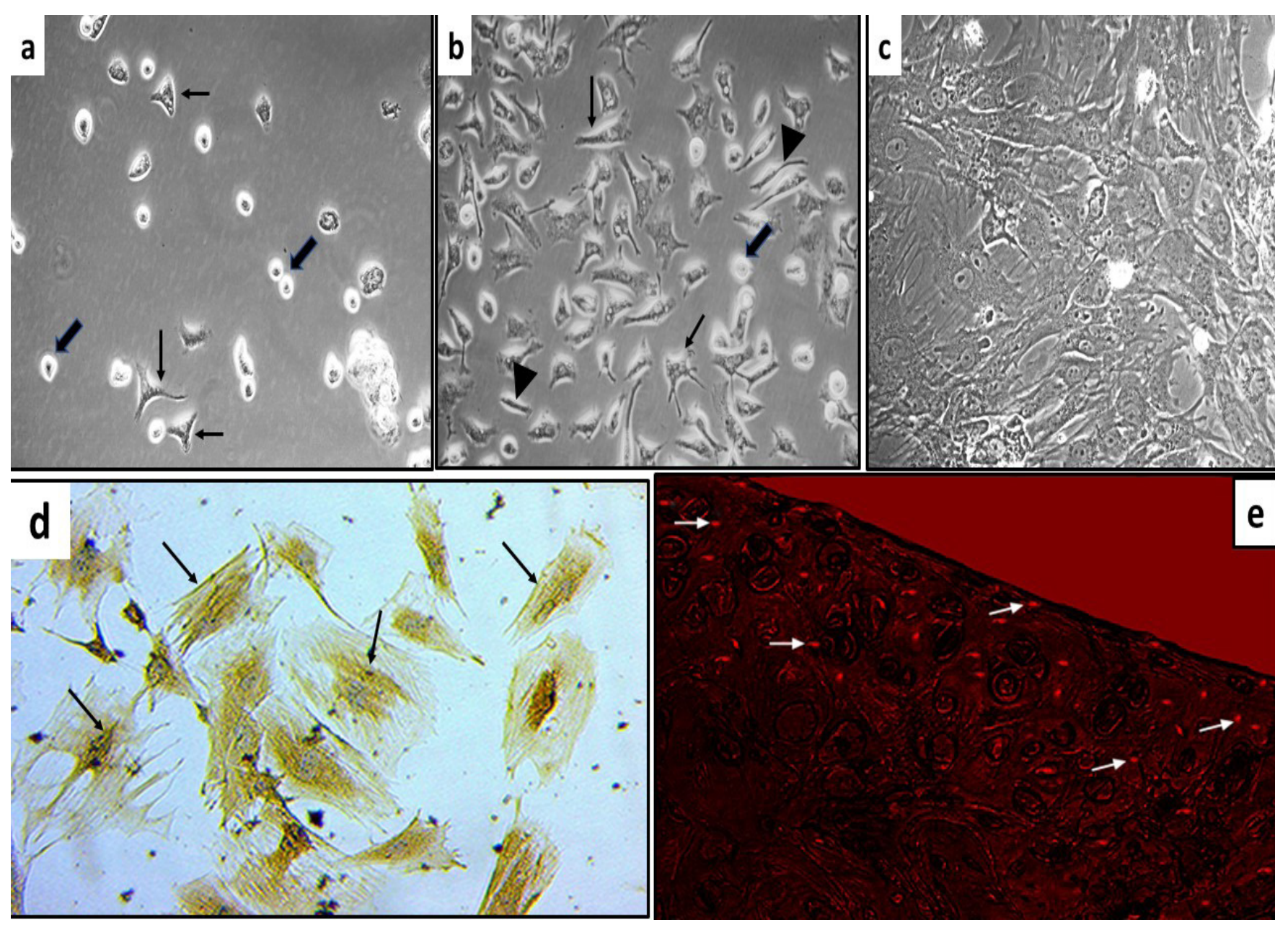

Fig 1: A photomicrograph showing: (a) Day three of primary culture: star shaped cells $(\uparrow)$ with thin short cytoplasmic processes. Some rounded shaped cells are suspended and refractile (thick arrow). (b) Day five of primary culture: elongated spindle shaped cells ( $\boldsymbol{\Delta}$ ) and star shaped cells with interconnected processes $(\uparrow)$. The cells have granular cytoplasm and central, vesicular nuclei. Few suspended, rounded and refractile cells are present (thick arrow). (c) Day nine of the primary culture: confluent, overcrowded cells having granular cytoplasm with central vesicular nuclei. The cells are interconnected through long cytoplasmic processes. (d) Day five of primary culture: positive brownish reaction to CD44 in most cells. (a, b, c and d "Phase contrast microscope X 200"). (e) Scattered positive fluorescence PKH-26 labeled cells in the articular cartilage matrix ( $\uparrow$ ). (Subgroup IId, fluorescence microscope X400). 


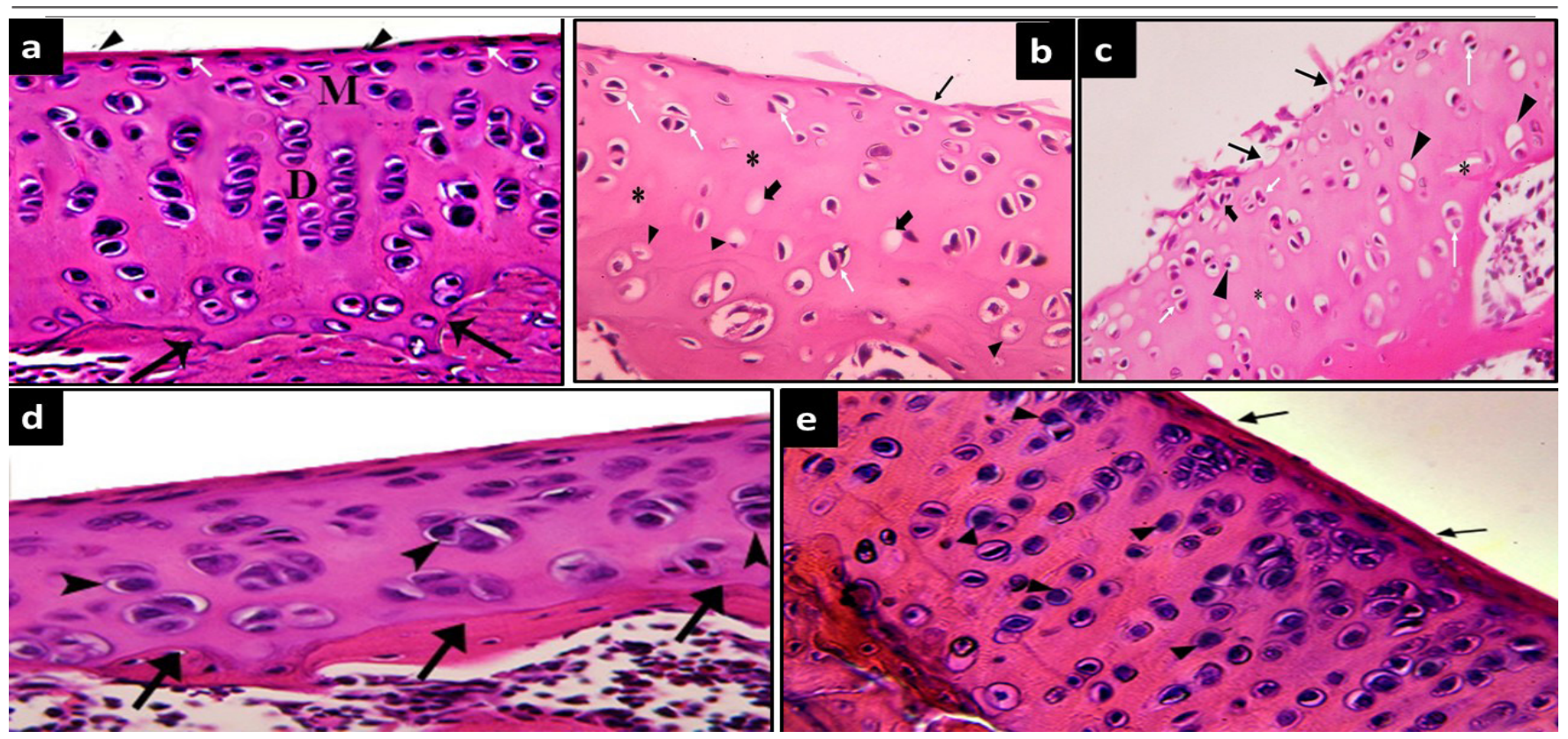

Fig. 2: A photomicrograph showing: (a) Control group: Regular smooth surface of the articular cartilage ( $\boldsymbol{\Delta}$ ). The chondrocytes are arranged into zones: Superficial tangential zone (white arrow); Middle zone (M); and deep zone (D) which is separated from the underlying calcified cartilage zone by the transverse tidemark ( $\uparrow)$. (b) Subgroup IIa: Slightly irregular articular surface $(\uparrow)$, poorly arranged chondrocytes, areas of chondrocytes' loss $(*)$, empty lacunae $($ thick arrow) and lacunae containing pyknotic nuclei ( $\mathbf{\Delta}$ ).Notice the presence of multiple scattered isogenous chondrocytes groups (white arrow) (c) Subgroup IIb: Marked surface erosions $(\uparrow)$, loss of chondrocytes' arrangement, lacunae appear empty or have degenerated shrunken chondrocyte with pyknotic nuclei $(\boldsymbol{\Delta})$. Fissuring of cartilage matrix $\left(^{*}\right)$ and ill-defined tidemark. Notice the presence of chondrocytes' clusters near the articular surface (thick arrow) and scattered isogenous groups (white arrow). (d) Subgroup IIc: Evident tidemark ( $\uparrow$ ), smooth articular surface, all lacunar spaces are occupied by irregularly arranged chondrocytes $(\boldsymbol{\Lambda})$ arranged as isogenous groups. Cartilage matrix is intact. (e) Subgroup IId: Smooth articular surface ( $\uparrow$ ), all lacunar spaces are occupied by chondrocytes $(\boldsymbol{\Delta})$ and are almost organized into layers. The cartilage matrix is intact (H\&E stain $\mathrm{x} 400)$.

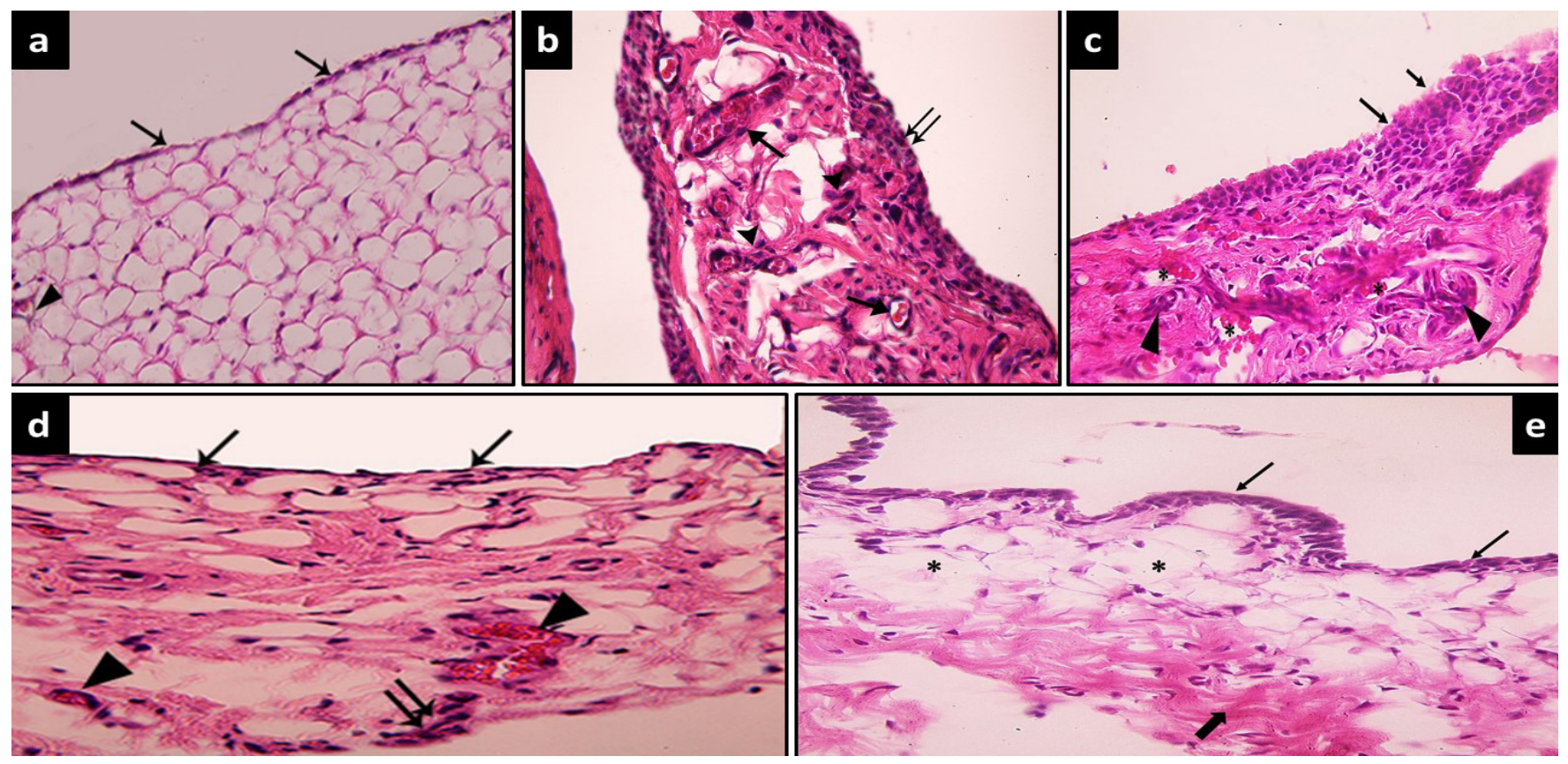

Fig. 3: A photomicrograph showing: (a) Control group: Thin intimal lining formed of a single cell layer ( $\uparrow$ ). The subintimal stroma contains evident fat cells and few thin walled blood vessels $(\boldsymbol{\Delta})$. (b) Subgroup IIa: Thickening of the intimal lining forming stratified layers of cells in some areas ( $\uparrow$ ), inflammatory infiltrates in the subintimal stroma $(\boldsymbol{\Delta})$ and evident dilated congested blood vessels $(\uparrow)$. (c) Subgroup IIb: The intimal lining shows thick stratified layers $(\uparrow)$, the subintimal stroma shows localized inflammatory aggregates $(\boldsymbol{\Delta})$, scattered inflammatory cells and congested blood vessels $(*)$. (d) Subgroup IIc: Relatively thin intimal lining $(\uparrow)$ and scattered few inflammatory cells $(\uparrow \uparrow)$. Notice the congested blood vessels $(\boldsymbol{\Delta})$. (e) Subgroup IId: Relatively thin intimal lining $(\uparrow)$. The subintimal stroma shows fat cells $\left(^{*}\right)$ at the superficial part, collagen fibers in the deep part (thick arrow) and few scattered inflammatory cells. (H\&E stain $\mathrm{x} 400)$. 


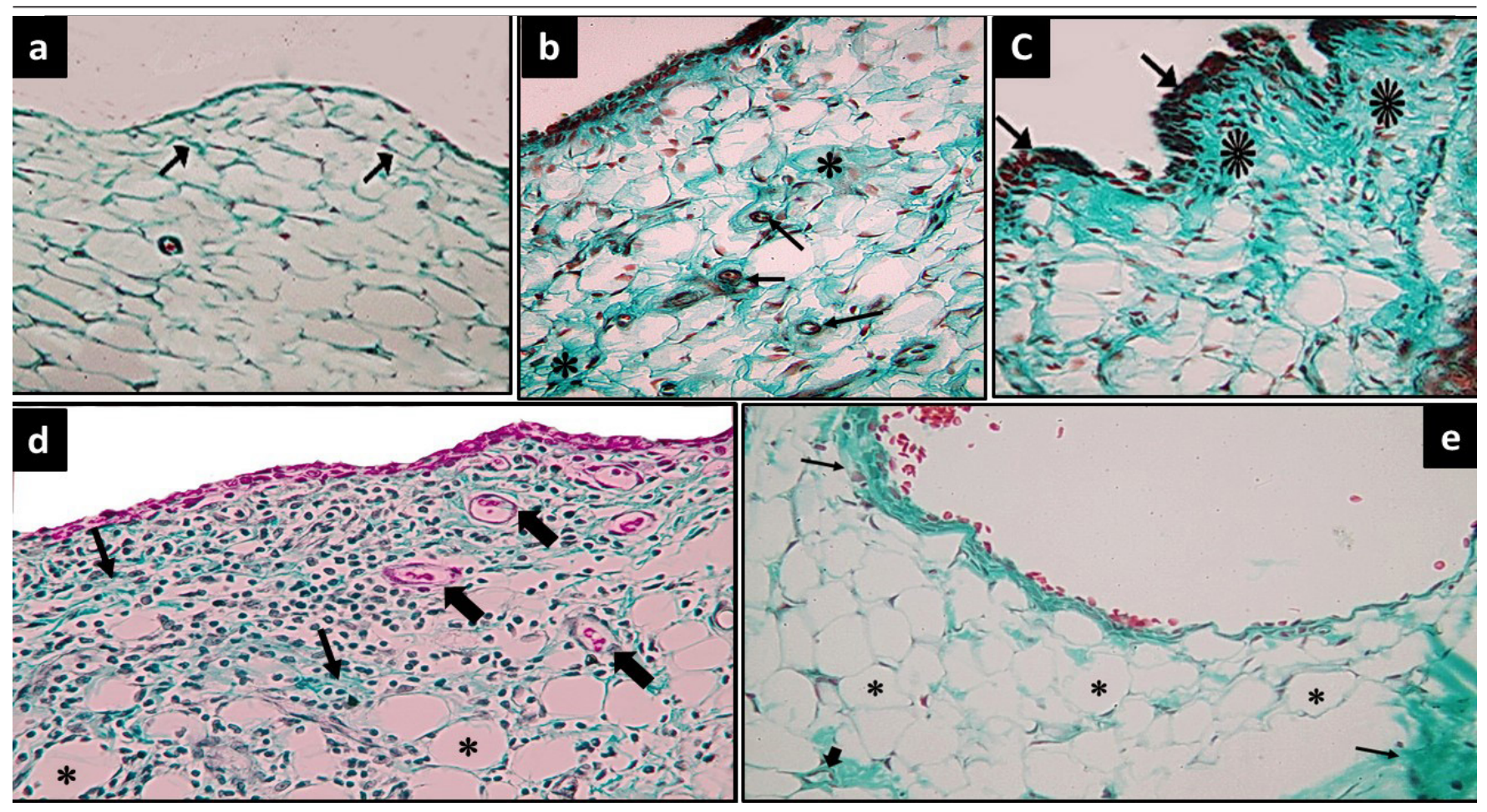

Fig 4: A photomicrograph showing: (a) Control group: Few scattered collagen fibers in the subintima (arrow). (b) Subgroup IIa: Marked deposition of collagen in the subitima $(*)$ and evident blood vessels (arrow). (c) Subgroup IIb: Marked increase in the amount of collagen content in the subintima (*) and villous formation (arrow). (d) Subgroup IIc: Moderate content of collagen in the subintima (thin arrow), scattered inflammatory cells, many blood vessels (thick arrow) and fat cells (*). (e) Subgroup IId: Minimal scattered collagen fibers in the subintimal stroma (thin arrow;1), few blood vessels (thick arrow) and evident fat cells $\left(^{*}\right)$. (Masson's trichrome stain $\left.\mathrm{x} 400\right)$.

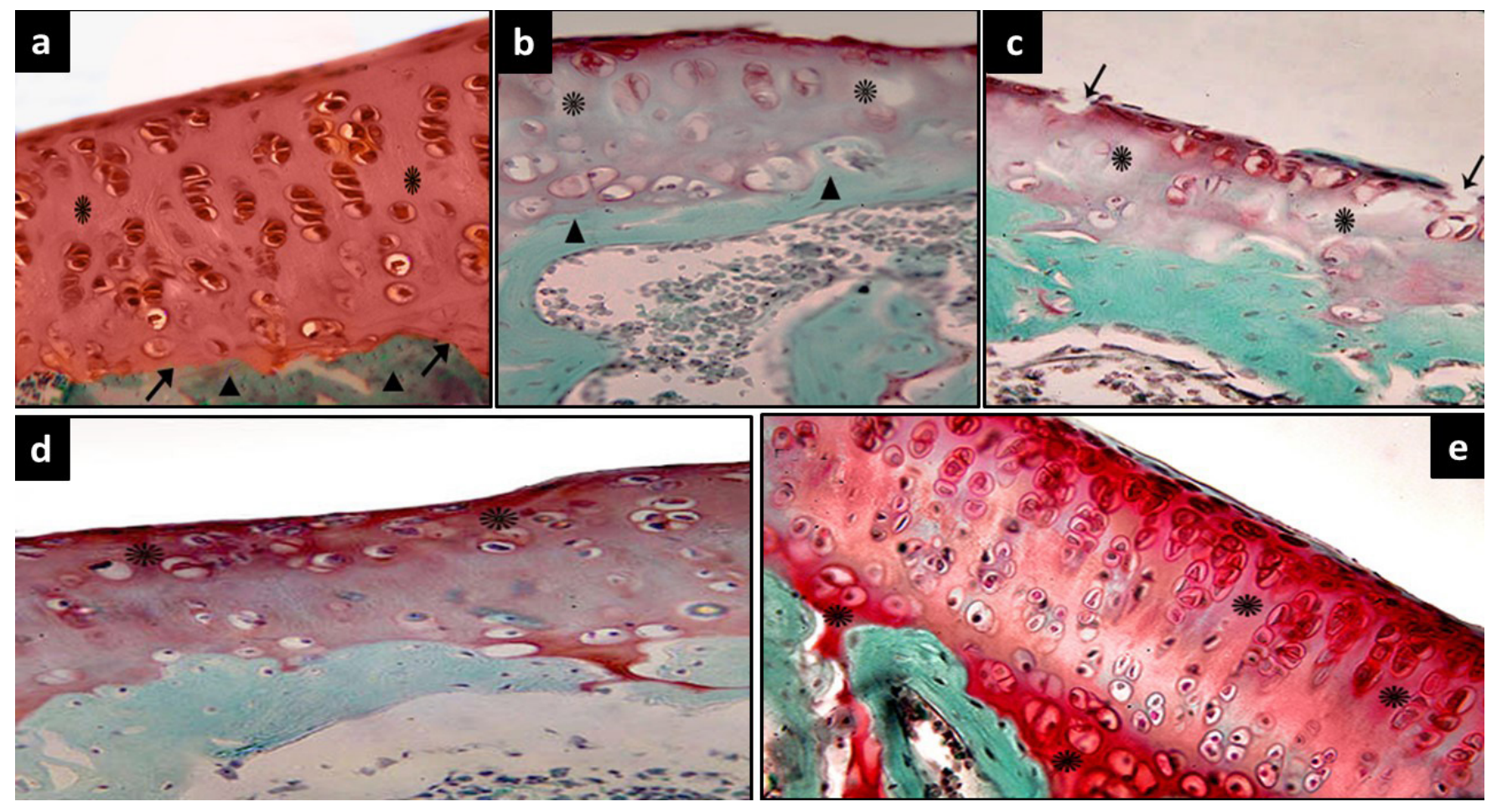

Fig 5: A photomicrograph showing: (a) Control group: Homogenous orange color of the ground substance of the articular cartilage $(*)$ and evident tidemark $(\uparrow)$ separating the deep cartilage zone from the calcified zone $(\boldsymbol{\Delta})$. (b) Subgroup IIa: Decreased intensity of the Safranin O stain of cartilage matrix $(*)$. Notice the different staining of the underlying bone matrix $(\mathbf{\Delta})$. (c) Subgroup IIb: Faint staining of the ground substance in between chondrocytes $(*)$. Notice irregular surface of the articular cartilage $(\uparrow)$. (d) Subgroup IIc: Relative increase in the staining intensity of Safranin O stain of the cartilage matrix especially in the upper zone (*). (e) Subgroup IId: Apparent increase in intensity of the Safranin O stain of the cartilage matrix especially in the upper and deep zones (*). (Safranin O stain X 400) 


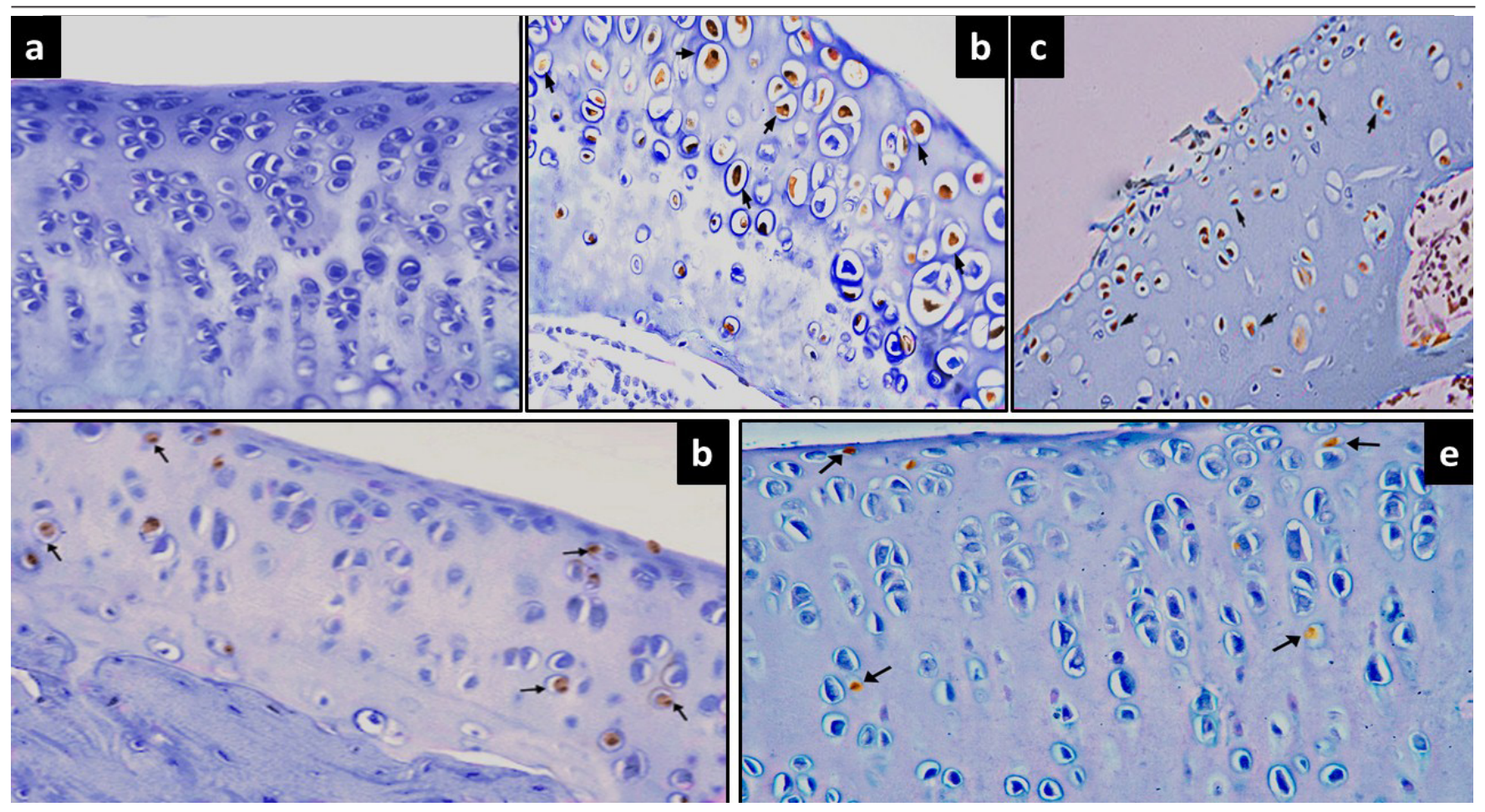

Fig 6: A photomicrograph showing: (a) Control group: Negative iNOS immuno-staining of chondrocytes. (b) Subgroup IIa: Many iNOS-positive chondrocyte $(\uparrow)$. (c) Subgroup IIb: Many iNOS-positive chondrocyte ( $\uparrow)$. (d) Subgroup IIc: Few iNOS-positive chondrocyte ( $\uparrow$ ). (e) Subgroup IId: Few scattered iNOSpositive chondrocyte $(\uparrow)$. (iNOS immunostaining counter stained with $\mathrm{Hx} \times 400)$

Table 1: Mean \pm SD of Cartilage thickness, safranin O color density, number of iNOS positive chondrocytes and area percentage of collagen fibers in different subgroups:

\begin{tabular}{|c|c|c|c|c|}
\hline & Cartilage thickness $(\mu \mathrm{m})$ & Safranin O color density & $\begin{array}{l}\text { iNOS positive chondrocytes } \\
\qquad\left(\text { cells } / \mu \mathrm{m}^{2}\right)\end{array}$ & $\begin{array}{c}\text { Area } \% \text { of collagen fibers } \\
\text { in synovial membrane }\end{array}$ \\
\hline Group I & $142.75 \pm 1.71$ & $36.59 \pm 1.40$ & 0.00 & $16.39 \pm 1.40$ \\
\hline (Control) & $(\mathbf{\Delta})$ & $(\boldsymbol{\Delta} \mathrm{O})$ & & $(\boldsymbol{\Delta} \mathrm{O})$ \\
\hline \multirow[t]{2}{*}{ Subgroup IIb } & $43.19 \pm 4.74$ & $18.44 \pm 1.19$ & $16.00 \pm 3.19$ & $46.72 \pm 1.59$ \\
\hline & $(* \mathrm{O} \mathbf{)})$ & $(* \mathrm{O} \mathbf{2})$ & $(* \mathrm{O})$ & $(* \mathrm{O} *)$ \\
\hline \multirow[t]{2}{*}{ Subgroup IIc } & $136.44 \pm 3.36$ & $29.26 \pm 1.72$ & $2.10 \pm 0.87$ & $25.25 \pm 0.87$ \\
\hline & $(\mathbf{\Delta})$ & $(* \Delta *)$ & $(* \mathbf{\Delta})$ & $(* \Delta *)$ \\
\hline \multirow[t]{2}{*}{ Subgroup IId } & $141.14 \pm 1.20$ & $35.72 \pm 1.40$ & $1.00 \pm 0.81$ & $18.40 \pm 2.21$ \\
\hline & $(\boldsymbol{\Delta})$ & $(\boldsymbol{\Delta} \mathrm{O})$ & $(\mathbf{\Delta})$ & $(\boldsymbol{\Delta} \mathrm{O})$ \\
\hline
\end{tabular}

* Significant difference from the control group.

$\Delta$ Significant difference from subgroup IIb

O Significant difference from subgroup IIc

* Significant difference from group IId. 


\section{DISCUSSION}

Rheumatoid arthritis is an autoimmune disease of unknown etiology characterized by chronic progressive joint inflammation with subsequent cartilage and bone destruction $^{[2]}$. Administration of MTX is a widely used method of treating RA. Methotrexate slows the rate of joint destruction through its inhibitory effects on the cascade of events initiated by inflammatory cytokines and subsequent joint-destructive enzymes ${ }^{[17]}$.

However, MTX treatment has no effect on regeneration of damaged articular cartilage. Thus, cartilage repair through cell therapy was a challenge. The regenerative potential of MSCs has been under intense investigation because of their ability for self-renewal and differentiation to reconstitute muscle, cartilage, or bone ${ }^{[18]}$.

In the current study, synovial membranes of the subgroup IIa (early RA), showed thick intimal lining, infiltration of the subintimal stroma with inflammatory cells, dilated congested blood vessels and villous formation. These findings were more profound in the progressive stage of the disease in subgroup IIb (late RA). The same findings were recorded by other investigators ${ }^{[19]}$, who suggested that RA is initiated in the synovial membrane where swelling and congestion lead to infiltration by immune cells followed by synovium thickening which is the major contributor to cartilage damage in RA.

These inflammatory cells were suggested to be due to increased levels of nitric oxide (NO) production from macrophage and endothelium leading to hypoxic environment that stimulates vessel dilatation and increased permeability, facilitating edema formation and immune cell extravasation $^{[20]}$.

The relative increase of blood vessels in the subintimal stroma of the synovium in the RA subgroups might be explained on basis that inflammatory cells which infiltrate the subintimal stroma of the synovium are capable of induction of angiogenesis directly by producing angiogenic factors and/or indirectly through secreting cytokines that stimulated fibroblast to release angiogenic factors ${ }^{[20]}$.

In the present study, significant increase in the area percentage of collagen was detected in the synovium of RA subgroups compared to other groups. Similar results were reported by other studies ${ }^{[7,21]}$ but with no clear explanation of the mechanism for such increase. We assumed that RA fibroblast cells were not only activated to produce destructive enzymes but also were stimulated to produce collagen fibers in significant amounts.

In the current study, $H \& E$ stained cartilage sections showed signs of cellular and matrix degeneration in early and late RA. Cartilage damage in RA was suggested to be due to the destructive action of an inflammatory synovial pannus. Cartilage erosion usually starts at the sites of contact with pannus tissue which destroy cartilage by increasing proteolytic activity. Moreover, synovial fibroblasts could invade the articular cartilage at the affected joint or could secrete destructive enzymes in the synovial fluid ${ }^{[19]}$.

Mononuclear cellular infiltrate in the subintima of the synovium secrete certain factors as TNF- $\alpha$, IL- 1 and IL-6 which bound to chondrocytes receptors' leading to the release of matrix metallo-protineases (MMPs) that can degrade all component of the extracellular matrix, as well as inhibiting type II collagen production, hence enhancing cartilage degradation $^{[22]}$. This could explain the fissuring of the matrix noticed in the present study in late RA (subgroup IIb) Furthermore, fissure formation could also be attributed to change in the type of the collagen in the articular cartilage from collagen type II to collagen type I leading to reduction in cartilage ability to store elastic energy ${ }^{[23]}$.

In the present study, chondrocytes were poorly arranged into layers in RA subgroups and were rather arranged into either clusters or isogenous groups. Sandell and Aigner, $2001^{[24]}$ stated that normal articular chondrocytes have no proliferative activity, in contrast, there is a low proliferative activity in osteoarthritic chondrocytes. They suggested that, the activity seen in osteoarthritic chondrocytes might be due to better access of proliferative factors to chondrocytes from the synovial fluid through fissuring or loosening of the collagen network, or due to the damage to the collagen matrix itself.

In this study, empty lacunae were detected in RA subgroups suggesting chondrocytes' death. Other studies have reported the apoptotic cell death as a dominant event in the degeneration of osteoarthritic cartilage ${ }^{[24,25]}$. Nitric oxide (NO) was claimed to play a role in apoptosis of chondrocytes and synovial cells ${ }^{[26]}$. These apoptotic chondrocytes are not removed effectively from cartilage due to poor blood supply, and the products of cell death such as pyrophosphate and precipitated calcium may contribute to pathologic cartilage degradation $^{[24]}$.

The significant decrease of the cartilage thickness in RA subgroups of the present study was in accordance with other studies ${ }^{[27,28]}$. They attributed this to either invasion by proliferative fibrous tissue from the underlying bone or adjacent synovial tissues that leads to cartilage degradation.

Although MTX showed relative improvement of the structure of the cartilage and synovium structure in our study and other studies ${ }^{[29,30]}$, due to its action that could prevent proliferation of monocytes, macrophages and synoviocytes, decrease synthesis of leukotriens in neutrophils, hold up cellular immunity and exert an anti-proliferative influence on endothelial cells. However, Kim et al., 2015 ${ }^{[17]}$ considered poor organization of chondrocyte to be an adverse effect of MTX treatment

The anti-inflammatory effects of MTX could be attributed to inhibition of proliferation of the cells responsible for 
synovial inflammation in RA; inhibition of the synthesis of potentially toxic compounds as mettallo-collangeolytic enzymes; reduction of macrophage recruitment and release of high concentrations of adenosine from cells and tissues ${ }^{[17]}$.

The remarkable improvement of the structure of the cartilage and synovium in the current study after MSCs treatment (subgroup IId) was also observed in other studies ${ }^{[6,7]}$. This effect might be either due to differentiation to tissue cells and restoration of lost morphology and function, or secretion of a wide range of bioactive and growth factors such as: fibroblast growth factor, epidermal growth factor, plateletderived growth factor, and vascular endothelial growth factor which create a repair environment with anti-apoptotic effects, immune-regulatory function and the stimulation of endothelial progenitor cell proliferation ${ }^{[31]}$.

Hoogduijn et al., 2010 ${ }^{[32]}$ added that MSCs could alter the cytokine secretion profile of immune cells such as decreasing TNF- $\alpha$ and interferon- $\gamma$ secretion and increasing the secretion of suppressive cytokines (IL-4 and IL-10). This shift from a pro-inflammatory to a beneficial anti-inflammatory response was of therapeutic advantage.

Whether MSCs could perform its immunomodulatory effect in severe inflammatory conditions is a controversial issue, Klinker and Wei, 2015 $5^{[33]}$ reported that the immunosuppressive capacity of MSCs was enhanced strongly under inflammatory conditions, and their differentiation capacity was preserved. On the contrary, Papadopoulou et al., 2012 $2^{[9]}$ stated that MSCs lost their immune-modulatory properties when infused in inflammatory autoimmune arthritis as increased levels of TNF- $\alpha$ was shown to reverse the immune-suppressive properties of MSCs.

Staining of the cartilage ground substance in the present study by Safranin $O$, that stains proteoglycans in matrix, revealed significant low color density in the RA subgroup and MTX treated group compared to control and MSCs treated subgroups. Degraded cartilage matrix components are considered both as diagnostic marker of cartilage damage and as potential autoantigens in the induction and maintenance of RA synovial inflammation ${ }^{[34]}$

Cartilage proteoglycans are capable of binding in a specific fashion to hyaluronic acid. Such associations produce large multimolecular aggregates, which are maintained within the extracellular matrix by a network of type II collagen ${ }^{[35]}$. Cartilage matrix molecules provide cushioning of the cartilage in the joint. Loss of ground substance in turn allow a greater susceptibility to damage from compressive forces and greater penetration of degenerative molecules leading to surface erosions ${ }^{[36]}$.

It is generally accepted that the degree of positive staining of Safranin O corresponds with the amount of proteoglycans in matrix ${ }^{[36,37]}$. Moreover, reversible matrix staining loss is characteristic of the effects of proteolytic enzymes as metalloproteinases and aggrecanases which might be derived either from cartilage or from synovium, whereas, permanent matrix staining loss results from cell death (necrosis and apoptosis) coupled with inhibition of chondrocyte proliferation $^{[28]}$.

In this view, Felson, 2006 ${ }^{[38]}$ explained that degeneration of cartilage in osteoarthritis is characterized by two phases: a biosynthetic phase, during which the chondrocytes attempted to repair the damaged extracellular matrix; and a degradation phase, in which the activity of enzymes produced by the chondrocytes digests the matrix. Consequently, matrix synthesis is inhibited, and erosion of the cartilage is accelerated.

In MSCs treated subgroup, the consistent staining of the ground substance by Safranin O was attributed probably to the decrease in inflammatory cytokines as TNF- $\alpha$ and the release of anti-inflammatory substances which influence matrix turnover and inhibit proteoglycan degradation ${ }^{[5]}$. On the other hand, in MTX treated subgroup, there was a significant decrease in the color density of the ground substance reflecting depletion of proteoglycans.

Inducible nitric oxide synthase (iNOS) is a member of the nitric oxide synthase family. It is a pro-inflammatory marker which is known to increase in chronic inflammatory conditions and induce apoptosis, and matrix degradation through creating oxidative environments ${ }^{[14]}$. In the current study, statistical analysis of the mean number of iNOS positive chondrocytes revealed significant increase in number in RA subgroup, while a non- significant change was measured between MTX and MSCs treated groups.

Nitric oxide was found to cause hypoxia through inhibition of cell respiration by binding to cytochrome $\mathrm{c}$ oxidase, which in turn induces synovial angiogenesis that enables activated monocytes to invade the synovium and extend into the pannus, leading to bone and cartilage destruction. In addition, hypoxic media can induce degeneration of synoviocytes and chondrocytes, inhibition of collagen and proteoglycan synthesis and activation of matrix MMPs, which led to the articular cartilage degradation ${ }^{[26]}$.

The decrease in the number of iNOS positive chondrocytes in MTX and MSCs treated groups was attributed to their antiinflammatory and immunomodulatory effect as mentioned before.

In conclusion, our study showed that intra-articular injection of BM-MSCs was more effective than MTX in restoration of knee joint structure in a rat model of RA.

\section{RECOMMENDATIONS:}

Based on the results of the current study, intra articular stem cells' injection might represent a new promising therapy for the treatment of rheumatoid arthritis. Moreover, further studies on the effect of MSCs injection in early RA are recommended. 


\section{POTENTIAL CONFLICT OF INTEREST}

The authors have no conflicting financial interest.

\section{REFERENCES}

1. Shikha S, Shatish P, Daharwal S J, Singh D, Singh M. Rheumatoid Arthritis: An autoimmune disease prevalent in females; Res J Pharma Tech 2016; 9: 170- 172 .

2. Karmakar S, Kay J, Gravallese EM. Cartilage and bone damage in rheumatoid arthritis: mechanistic insights and approaches to prevention. Rheum Dis Clin North Am 2010; 36:385-404

3. Krause D, Gabriel B, Herborn G, Braun J, Rau R. Response to methotrexate predicts long-term patientrelated outcomes in rheumatoid Arthritis. Clin Rheumatol 2016; 35:1123 - 1127

4. Lin $\mathrm{M}$, Lin B, Lars L, Yonglun W. Towards personalized regenerative cell therapy: Mesenchymal stem cells derived from human induced pluripotent stem cells. Curr Stem Cell Res \& Therapy 2016; 11: $122-130$.

5. Kehoe O, Cartwright A, Ayman A, Alicia J, and Jim M (2014): Intra-articular injection of mesenchymal stem cells leads to reduced inflammation and cartilage damage in murine antigen-induced arthritis. J Transl Med 2014; 45: 152157-.

6. Singh A, Goel S C, Gupta K K, Kumar M, Arun G R, Patil H, Kumaraswamy V, Jha S. The role of stem cells in osteoarthritis: An experimental study in rabbits. Bone Joint 2013; 3:32-37.

7. Greish S, Abogresha N, Abdel-Hady Z, Zakaria E, Ghaly M, Hefny M. Human umbilical cord mesenchymal stem cells as treatment of adjuvant rheumatoid arthritis in a rat model. World J Stem Cells 2012; 4: 101 - 109.

8. Wang YQ, Cao XF, He ZM, Xiao FJ, Wang HX, Guo ZK. Human bone marrow mesenchymal stem cells have little preventive or therapeutic effect on rat arthritis induced by collagen. Chin Ass Path physiol 2012; 20:433 - 437

9. Papadopoulou A, Yiangou M, Athanasiou E, Zogas N, Kaloyannidis P, Batsis I, Fassas A, Anagnostopoulos A, Yannaki E. Mesenchymal stem cells are conditionally therapeutic in preclinical models of rheumatoid arthritis. Ann Rheum Dis 2012; $71: 1733$ - 1740 .
10. Tuncel J, Haag S, Hoffmann MH, Yau ACY, Hultqvist M, Olofsson P, Bäcklund J, Nandakumar KS, Weidner D, Fischer A, Leichsenring A, Lange F, Haase C, Lu S, Gulko PS, Steiner G, Holmdahl R. Animal Models of Rheumatoid Arthritis (I): PristaneInduced Arthritis in the Rat. PLoS ONE 2016; 11(5): e0155936.

11. Nazemian V, Nasseri B, Manaheji H, Zaringhalam J. Effects of mesenchymal stem cells conditioned medium on behavioral aspects of inflammatory arthritic pain. J cell Mole Anesth 2016; 1:47 - 55.

12. Bauerova K, Paulovičova E, Mihalova D, Drafi F, Ktrosova M, Mascia C, Biasi F, Rovensky J, Kucharska J, Gvozdjakova A. Combined methotrexate and coenzyme Q10 therapy in adjuvantinduced arthritis evaluated using parameters of inflammation and oxidative stress. Acta Biochim Pol 2010; 57:347-354.

13. Schmitz N, Lavertyz S, Krausx VB, Aignerk T. Basic methods in histopathology of joint tissues. Osteoarth Cartil 2010; $18: 113$ - 116

14. Chou LW, Wang J, Chang PL, Hsieh YL. Hyaluronan modulates accumulation of hypoxia-inducible factor-1 alpha, inducible nitric oxide synthase, and matrix metalloproteinase- 3 in the synovium of rat adjuvant induced arthritis model. Arthritis Res Ther 2011; 13:90 - 95

15. Sun S, Guo Z, Xiao X, Liu B, Liu X, Tang PH and Mao N. Isolation of mouse marrow mesenchymal progenitors by a novel and reliable method. Stem Cells 2003; 21: 527 - 535 .

16. Li H, FuX, Ouyang Y, Cai C, Wang J, and Sun T. Adult bone-marrow-derived mesenchymal stem cells contribute to wound healing of skin appendages. Cell Tiss Res 2006; 32(3):723 - 725.

17. Kim YH, Kang JS. Effect of methotrexate on collagen-induced arthritis assessed by microcomputed tomography and histopathological examination in female rats. Biomol Ther 2015; 23 . $195-200$.

18. Jorgensen C, Noel D, Apparailly F, Sany J. Stem cells for repair of cartilage and bone: the next challenge in osteoarthritis and rheumatoid arthritis. Ann Rheum Dis 2001; 60: 305-309

19. Pap T, Ulf M, Renate E, Steffen G. Fibroblast biology: Role of synovial fibroblasts in the pathogenesis of rheumatoid arthritis. Arthritis Res 2000; 2: 361-367 
20. Bonnet CS, Walsh DA. Osteoarthritis, angiogenesis an inflammation. Rheumatology 2005; 44: 7-16.

21. Lahm A, Mrosek E, Spank H, Erggelet C, Kasch R, Esser J, Merk H (2010): Changes in content and synthesis of collagen types and proteoglycans in osteoarthritis of the knee joint and comparison of quantitative analysis with photoshop-based image analysis. Archives of Orthopaedic and Trauma Surgery; 130(4):557-564.

22. Tak M, Bresnihan B. The pathogenesis and prevention of joint damage in rheumatoid arthritis: Advances from synovial biopsy and tissue analysis. Arthritis Rheum 2000; 43: 2619 - 2633.

23. Silver F H, Bradica G, Tria A. Elastic energy storage in human articular cartilage: estimation of the elastic modulus for type II collagen and changes associated with osteoarthritis. Matrix Biology 2002; 21:129 137.

24. Sandell L J and Aigner T. Articular cartilage and changes in arthritis. An introduction: Cell biology of osteoarthritis. Arthritis Res 2001; 3:107-113.

25. Kim HA, Lee YJ, Seong SC, Choe KW, Song YW. Apoptotic chondrocyte death in human osteoarthritis. J Rheum 2000; 27:455-462.

26. Amin A, Abramson S: The role of nitric oxide in articular cartilage breakdown in osteoarthritis. Curr Opin Rheumatol 1998,10:263-268

27. Soliman NE. Effect of intra-articular injection of high-molecular-weight versus low-molecular-weight hyaluronic acid on the articular cartilage structure in experimentally induced knee joint osteoarthritis in albino rats. Egypt J Histo 2012; 35: 483 - 495

28. Yatsugi N, Tsukazaki T, Osaki M, Koji T, Yamashita $\mathrm{S}$, Shindo H. Apoptosis of articular chondrocytes in rheumatoid arthritis and osteoarthritis: correlation of apoptosis with degree of cartilage destruction and expression of apoptosis-related proteins of p53 and c-myc. Orthop Sci 2000; 5: 150 - 156.

29. Cutolo M, Sulli A, Pizzorni C, Seriolo B. Antiinflammatory mechanisms of methotrexate in rheumatoid arthritis. Anna Rheum Dis 2001; 60: 729- 735 .
30. Mello SB, Barros DM, Silva AS, Laurindo IM, Novaes GS. Methotrexate as a preferential cyclooxygenase 2 inhibitor in whole blood of patients with rheumatoid arthritis. Rheumatology 2000; 39: 533-536.

31. Augello A, Kurth T, De Bari S. Mesenchymal stem cells: A perspective from in Vitro cultures to in Vivo migration and niches. Euro Cells materials 2010; 20: $122-133$

32. Hoogduijn MJ, Popp F, Verbeek R, Masoodi M, Nicolaou A, Baan C, Dahlke MH. The immunomodulatory properties of mesenchymal stem cells and their use for immunotherapy. Int Immuno Pharmacol 2010; 10: 1496- 1500.

33. Klinker MW, Wei CH. Mesenchymal stem cells in the treatment of inflammatory and autoimmune diseases in experimental animal models. World J Stem Cells 2015; 7: 556-567.

34. Goldring M B and Otero M. Cells of the synovium in rheumatoid arthritis. Chondrocytes. Arthritis Res Ther. 2007; 9: 220 .

35. Wall A. and Board T. Chemical Basis for the Histological Use of Safranin O in the Study of Articular Cartilage. In: Banaszkiewicz P., Kader D. (eds) Classic Papers in Orthopaedics, Springer, London; 2014: 433 - 435.

36. Moody H R, Arafa I O, Singh S, Oloyede A. Potential enhancement of articular cartilage histological grading with collagen integrity. Clin Biomech 2018;56: 1 - 10.

37. Chevrier A, Rossomacha E, Michael D, Baschmann, Caroline D. Optimization of histo-processing methods to detect glycosaminoglycans, collagen type II, collagen type I in decalcified rabbit osteochondral sections. J Histo 2005; 28(3):1 - 11.

38. Felson DT. Clinical practice. Osteoarthritis of the knee. NEJM 2006; 354: 841-848. 


\section{تأثير الخلايا الجذعية الوسطى المثتقة من النخاع العظمي مقارنة بعقار الميثوتريكسات في نموذج التهاب مفصل الركبة الروماتويدي في الجرذ. دراسة ماتهي

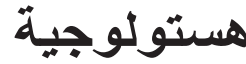

\section{سمية عبد العليم محمد ـ نهى عبد الحكم مخلوف - ولاء باهر - شيماء محمد عبود

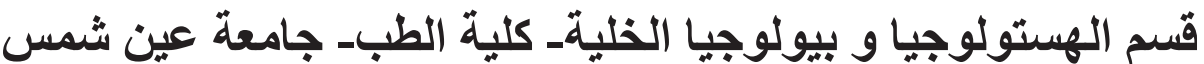

\section{ملخص البحث}

الخلفية والأهداف: التهاب المفاصل الروماتويدي هو أحد أمراض المناعة الذاتية التي تتميز بالتهاب المفاصل المزمن الذي يؤدي الى تدمير الغضروف. و وقد

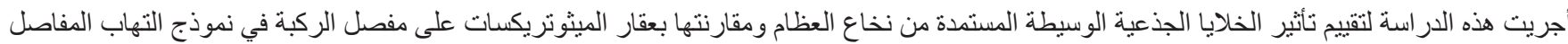
الروماتويدي في الجرذ.

المواد والطرق: تم استخدام خمسة واربعون من ذكور الجرذان البيضاء وتقسيمهم إلى مجمو عتين:

$$
\text { المجمو عة الأولى: المجموعة الضابطة (25 جرذ). }
$$

المجمو عة الثانية (20 جرذًا): نم استحداث التهاب المفاصل الروماتو يدي بهم، ثم تم تقسيم الجرذان إلى أربع مجمو عات فر عية. ــ المجمو عة الفر عية 2أو 2ب: تمت التضحية بهم بعد أسبو عين و أربعة أسابيع على التو الي من استحداث التهاب المفاصل الوماتويدي بها. ــ المجمو عة الفرعية 2ج: تمت معالجتها بعقار الميثوتركيسات بعد أسبو عين من استحداث التهاب المفاصل الروماتويدي بها ثم التضحية بها بعد أسبو عين من العلاج المجمو عة الفر عية 2د: تمت معالجتها بالخلايا الجذعبة الوسيطة المستمدة من نخاع العظام بعد أسبو عين من استحداث التهاب المفاصل الروماتو يدي بها ثم التضحية بها بعد أسبو عين من العلاج.

بعد التضحية بالجرذان, تم تشريح مفاصل الركبة و معالجتها للار اسات الهستولوجية و الهستوكيميائية و الهستوكيميائية المناعية.

النتائج: كثف الفحص النسيجي لمفاصل الركبة أن التهاب المفاصل الروماتويدي أسفر عن زيادة عدد الخلايا المبطنة للغثاء الزليلي مع وجود احتقان وتخلل بخلايا

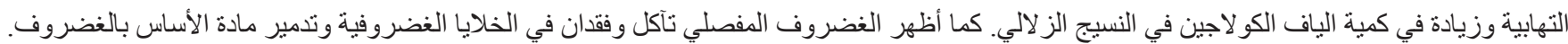

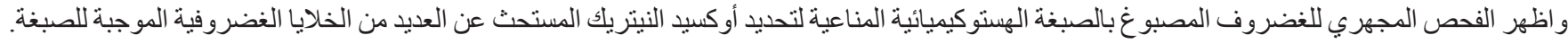
على الجانب الاخر فقد أدى حقن الخلايا الجذعية الوسيطة المستمدة من نخاع العظام إلى تحسين تركيب الغشاء الزليلي والغضروف المفصلي لمفصل الركبة بينما كان حقن عقار الميثوتريكسات أقل فعالية.

الخلاصة: ان حقن الخلايا الجذعية الوسيطة المستمدة من نخاع العظام داخل المفصل الركبة أدى إلى تحسن كبير في البنية النسيجية لمفصل الركبة في نموذج التهاب المفاصل الروماتويدي في الجرذ بالمقارنة مع عقار الميثوتريكسات. 